\title{
Case-based teaching research of media management course
}

\author{
Yan Zhang*, Heping Li \\ School of Journalism and Communication, Jiangxi Normal University, 330022 Nanchang City, \\ Jiangxi Province, China
}

\begin{abstract}
The Harvard case has made a profound contribution to business education around the world. The course of Media Management is about business. In order to improve its teaching efficiency, Media Management adopted case-based teaching, and integrates the question and answer teaching and the story teaching in the case-based teaching. It conducted a full course description in advance in the first two weeks of the term, introduced core concepts of media management, and then assigned research tasks for Chinese and foreign media enterprises. In the mid-stage, background,factual knowledge and conceptual knowledge were explained, related stories were integrated and case teaching and question-and-answer teaching were used to make the classroom more interesting and practical. In the mid-stage, We conducted comparative teaching for two majors, each of which has two parallel classes, One is in the presence of case-based teaching, and the other is in the traditional teaching. Results showed that case-based teaching could significantly improve students' academic performance. And the results also demonstrated that traditional teaching could improve students' academic performance moderately. Students in group shared their research reports at the end of the term. Students' group research report also enriched teachers' follow-up teaching resources.
\end{abstract}

\section{Introduction}

Education is the most sacred cause in the world, but it is also a perplexing cause. College teachers and students are largely helpless and confused. In college classrooms, at some point, students are the "victims" of the classroom, who have to endure the indoctrination of some boring teaching contents. Teachers may be ineffective in the classroom, who pay less attention to the structure of the content of the curriculum, transmit intensively information with hard work, but have to endure the absent-mindedness and indifference of students.

The essence of education is dialogue. Two masters in education of the East and the West, Confucius and Socrates, Both of them have used dialogue method in education. Confucius' dialogue took the form of questioning and answering to enlighten students' thinking and cognition, where students freely expressed their views or even debated with each other.

*Corresponding author: zhangyan2006@jxnu.edu.cn 
The Analects of Confucius records the dialogue between Confucius and his disciples in the form of dialogue laced with narratives. Coincidentally, Socrates advocated the Socratic method throughout his life where questioning and answering were the soul and remain popular till today. Paul Freire, a world-renowned Brazilian educator and philosopher, once remarked that "Without dialogue, there is no communication; without communication, there is no real education. " Freire argued that teachers should allow students to express their own "critical statements" to avoid silence in order to conduct a dialogue with students. Freire proposed for the first time that dialogue-based teaching should be applied in classroom[1]. Freire subtly combined personal anecdotes with detailed reflection in dialogue[2] and illustrated that dialogue was the key in teaching. Sages' understanding of dialogue-based education has given us a lot of enlightenment with regards to university classroom teaching.

In reality, college students tend to remain silent in dialogue, but it is suggested that teachers should use cases and stories related to curriculum contents to make the teaching interesting and to satisfy students. Let students become content in the classroom.

College teachers have the responsibility to interact with students well to improve the efficiency of teaching. The course of Media Management is a course about business operations. The Harvard case has made a profound contribution to business education around the world. "As professors, we have to distil complex business issues and bring them into the classroom, as students, they want to use these distilled experiences to make inferences." [3]says Michelle J. Roberts, a senior lecturer at Harvard Business School who leads case writing. So lecturers should choose good cases to ensure their utility.

Therefore, case-based teaching method was adopted to help students understand knowledge points and pave the way for teacher-student dialogues and student-student dialogues. In order to improve its teaching efficiency, a full course description was conducted in advance at the first two weeks. Besides, core concepts in media management were introduced to students who were also assigned to do investigate and survey about Chinese and foreign media companies which are chosen by them as a work group. In the mid-stage, background, factual knowledge and conceptual knowledge were explained, related stories were integrated and case-based teaching and question-and-answer teaching were used to make the classroom more interesting and practical. In the final stage, students shared their research reports in class, which might enrich teachers' Subsequent teaching resources.

\section{Materials and methods}

\subsection{Materials}

The teaching materials of media management mainly came from textbooks, reference books as well as cases and stories compiled by the teaching team. Videos of class instruction became the first-hand information for the teaching team to analyze the teaching effect and reflect on their teaching methods and design. In addition, suggestions and comments of supervisors at the school and college levels were valuable references for curriculum teaching analysis. Last, anonymous online evaluation of classroom teaching by students provides a window for the teaching team to learn about their teaching scientifically.

It can pro excellent feedback that the questionnaire surveys distributed among students and the comments given by students after the course, which can provide authentic feedback . The interviews with graduates helped the teaching team to revise their teaching to cultivate students' capabilities to adapt to the workplace requirements better in the near future. 


\subsection{Methods}

\subsubsection{Participans}

The participants in Media Management were mainly junior students from the Journalism and Communication College, majored in journalism and advertising. Media Management Program was a compulsory course for them. The teaching team began to use case teaching since 2009. The present participants came from two classes of Grade 2017, with a total of 113 students (as shown in Table 1). All present participants basically had no professional knowledge of media management, but with basic media market knowledge. In order to ensure the smooth progress of teaching activities, the first two weeks of teaching activities, a full introduction of the course was conducted in order to improve students ' understanding of the background knowledge of media management. Two classes of same major are parallel class, the difference between two classes in the same major is so small that it can be ignored.

Table 1. Information of participants.

\begin{tabular}{|c|c|c|}
\hline Grade & Journalism & Advertisement \\
\hline 2017 & 29 from Class 1 & 27 from Class 1 \\
\hline 2017 & 30 from Class 2 & 27 from Class 2 \\
\hline
\end{tabular}

\subsubsection{Instructional method \& Video observation method}

Various teaching methods were employed in media management course. They were case study teaching method, question and answer teaching method and story teaching. Questionand-answer teaching was integrated into case teaching, story teaching and lectures.The story teaching method is also integrated into the case teaching method.

At the same time, in order to observe the classroom teaching process anytime, anywhere, The whole teaching and learning process is recorded by two video cameras, one shooting teacher, another shooting students.

The process of teaching and learning in the classroom was recorded with one camera focusing on the lecturer and the other on students. The purpose was to observe classroom teaching and learning from different angels.

One class in journalism and in advertisement respectively were chosen randomly for case teaching and the other for regular lecturing without case study but based on textbook knowledge points. The process of teaching and learning in different classes is recorded. Students' classroom head-up rate and participation and engagement in the classroom question-and-answer session were compared.

But different class shared the same teaching objectives that were to help students to participate in concept learning, data analysis, problem solving and make reasonable decisions. In order to test the effectiveness of case teaching, the teaching team tried to integrate the course knowledge points into the relevant case.

Students' reports were videoed too with their consent so that video could be replied for further analysis of students' performance and interactions. All videos were taken with the student's consent and taken care of by the teacher with the sole purpose of classroom analysis. All video materials would be deleted within 2 months after the end of the course. 
In order to collect students' love for different forms of teaching, an 6-item questionnaire (Table 2.) was designed to test students' subjective fondness for various teaching activities. A 5-point Likert scale was used. Fondness degree increases with each increasing number. The survey's Cronbach'sa coefficient is high $(a=0.77)$, indicating that the survey has considerable credibility. Generally students find case-based teaching more popular than traditional classroom instruction, reading textbook, course assignments, group presentations and structured question-and-answer sessions. But story-based teaching was the most popular among students.

Table 2. An 6-item assessment instrument for students

\begin{tabular}{|l|l|}
\hline \multicolumn{1}{|c|}{ items } & scores \\
\hline 5) How much do you like the teacher's traditional classroom teaching?(1- & \\
\hline 2. How much do you like the cases presented by the teacher?(1-5) & \\
\hline 3. How much do you like the teacher's choice of textbooks?(1-5) & \\
\hline 4. How much do you like the Q\&A session designed by the teacher?(1-5) & \\
\hline 5. How much do you like the course assignment of the media company & \\
survey report undertaken by your group?(1-5) & \\
\hline 6. How much do you like the teacher's story-based teaching?(1-5) & \\
\hline
\end{tabular}

Note.on a 5-point Likert - type scale ranging froml( very dislike )to 5( very like)

\section{Results and Discussion}

\subsection{Background knowledge is important}

According to Bloom' $\mathrm{s}$ taxonomy[4], media management could be classified as shown in Table3.). Although the classification of Bloom's four main categories of knowledge is classic, background knowledge is very important for the learning of any course. Previous studies (Alexander, Kulikowich, \& Schulze, 1994 ; Shapiro, 2004 )[5,6] have shown that background knowledge plays an enormous role in reading comprehension. Background knowledge is what we call it domain-specific knowledge or thematic knowledge. [7]

Therefore, this course spent 6 hours in the first two weeks to introduce this course so that students could understand the basic conceptual knowledge, factual knowledge", "procedural knowledge", and "meta-knowledge knowledge" of media management. In the meanwhile, students could make use of the background knowledge as he key words to facilitate their research study in information retrieval at the end of the semester. Students were also encouraged to read widely on topics on media management. It turned out that developing students' background knowledge helped to lay a solid foundation for their courses and helped students to solidify their deeper understanding on topics related to media management. 
Table3.Main categories and sub-categories of Media Management knowledge.

\begin{tabular}{|c|c|}
\hline Main categories and Sub-categories & examples \\
\hline \multicolumn{2}{|c|}{$\begin{array}{l}\text { A.factual knowledge -- Essential elements that students must know to understand a subject or to } \\
\text { solve a problem }\end{array}$} \\
\hline A1.Knowledge of terminology & Cultural industry, media industry, content industry \\
\hline $\begin{array}{l}\text { A2.Knowledge of specific details and } \\
\text { elements }\end{array}$ & $\begin{array}{l}\text { Reliable sources of information (official website of the } \\
\text { Ministry of Culture, official website of the Bureau of } \\
\text { Statistics, annual report of listed media companies) }\end{array}$ \\
\hline \multicolumn{2}{|c|}{$\begin{array}{l}\text { B.conceptual knowledge-Relationships between the basic elements that work together within a } \\
\text { larger system }\end{array}$} \\
\hline $\begin{array}{l}\text { B1.Knowledge of classifications and } \\
\text { categories }\end{array}$ & $\begin{array}{l}\text { The categories of property rights of media enterprises } \\
\text { are divided into: public, private and state-owned }\end{array}$ \\
\hline $\begin{array}{l}\text { B2.Knowledge of principles and } \\
\text { generalizations }\end{array}$ & $\begin{array}{l}\text { Media enterprise content as the king, channel } \\
\text { amplification; concentration economy }\end{array}$ \\
\hline $\begin{array}{l}\text { B3.Knowledge of theories, models and } \\
\text { structures }\end{array}$ & $\begin{array}{c}\text { Economies of scale, Diseconomies of scale, economies } \\
\text { of scope, Diseconomies of scope; organization } \\
\text { framework of media companies }\end{array}$ \\
\hline \multicolumn{2}{|c|}{$\begin{array}{l}\text { C.Procedural knowledge - guidelines Methods, inquiry, and guidelines for using skills, algorithms, } \\
\text { techniques, and methods }\end{array}$} \\
\hline $\begin{array}{l}\text { C1.Knowledge of course-specific skills } \\
\text { and algorithms }\end{array}$ & $\begin{array}{c}\text { can understand the media enterprise's financial results, } \\
\text { can calculate the media enterprise's financing costs and } \\
\text { project profits }\end{array}$ \\
\hline $\begin{array}{l}\text { C2.Knowledge of course-specific } \\
\text { techniques and methods }\end{array}$ & $\begin{array}{c}\text { Can Pay attention to the interview programs of media } \\
\text { executives and collect information on their business } \\
\text { strategy and business strategy }\end{array}$ \\
\hline $\begin{array}{l}\text { C3.Knowledge of criteria for } \\
\text { determining when to use appropriate } \\
\text { procedures }\end{array}$ & $\begin{array}{l}\text { Can Determine under what circumstances to prioritize } \\
\text { the use of creditor's rights financing; } \\
\text { Determine under what circumstances equity financing } \\
\text { is preferred, }\end{array}$ \\
\hline \multicolumn{2}{|c|}{$\begin{array}{l}\text { D.metacognitive knowledge-Knowledge of general cognition and awareness and knowledge of self- } \\
\text { awareness }\end{array}$} \\
\hline D1.Strategic knowledge & $\begin{array}{c}\text { Knowing that the biography of a media entrepreneur is } \\
\text { a blue book to obtain the historical growth trajectory of } \\
\text { a media enterprise, and knowing that the official } \\
\text { website of a media enterprise generally has its } \\
\text { development memorabilia }\end{array}$ \\
\hline $\begin{array}{c}\text { D2.Knowledge about cognitive tasks, } \\
\text { including appropriate contexttual and } \\
\text { conditional knowledge }\end{array}$ & $\begin{array}{l}\text { Know the assessment requirements of media } \\
\text { management courses, and know the cognitive } \\
\text { requirements of different tasks; }\end{array}$ \\
\hline D3.Self-knowledge & $\begin{array}{l}\text { Know that presentation is their own strength / } \\
\text { weakness; } \\
\text { Know that doing data collection is their own strength / } \\
\text { weakness } \\
\text { Know that the construction case is their own strength / } \\
\text { weakness } \\
\text { Know that doing PPT is your own strength / weakness } \\
\text { Know that clip a visual audio material is your own } \\
\text { strength / weakness } \\
\text { Know how to improve? }\end{array}$ \\
\hline
\end{tabular}

Note: The above table is adaped from the book, A Taxonomy for Learning, Teaching, and AssessingA Revision of Bloom's Taxonomy of Educational Objectives (Complete Edition, Chinese version) (America)Lorin W. Anderson, (China)Xiaoping Jiang, Foreign Language Teaching and Research Press,22(2009) 


\subsection{Case-based teaching can significantly improve teaching}

In the third week after the introduction of the same teaching content and teaching form, two journalism classes were tested for background knowledge. Due to the same teaching content and teaching forms, the difference between the achievements of the two classes is not significant $\left(\mathrm{M}_{29}=86.51, \mathrm{SD}_{29}=8.54\right.$ VS. $\mathrm{M}_{30}=85.57, \mathrm{SD}_{30}=8.72$, Cohen' $\mathrm{s}=0.11$, as show in Table4.).

But after the implementation of case teaching method, the analysis of the previous and post-test data showed that case teaching could significantly improve students' academic performance ( Mpretest=72.79, SDpretest=14.59 VS. Mpost test=86.09, SDpost test $=12.17$, Cohen's $=0.99$, as show in Table4. ).

After the implementation of traditional classroom teaching, the analysis of the pre-test and post-test data revealed that case teaching could improve academic performance moderately (Mpretest $=72.08$, SDpretest $=17.08$ VS. Mpost test $=80.45$, SDpost test $=13.67$, Cohen's=0.54,as show in Table4. ).

In terms of post-measurement data of comparing case teaching and traditional classroom teaching, case teaching could improve academic performance in a moderate way (Mcase $=86.09$, SDcase $=12.17$ VS. Mlecture $=80.45$, SDlecture $=13.67$, Cohen's $=0.44$, as show in Table4.).

Table4.Means and SDs of Background Knowledge, Pretest and Post test Scores in Different of the version of the content in Media management course for Journalism

\begin{tabular}{|c|c|c|c|c|c|c|c|}
\hline \multicolumn{2}{|c|}{$\begin{array}{c}\text { Background } \\
\text { knowledge }\end{array}$} & & \multicolumn{2}{c|}{ pretest } & \multicolumn{2}{c|}{ Post test } \\
\hline M & SD & N & Teaching form & M & SD & M & SD \\
\hline 86.51 & 8.54 & 29 & Case-based & 72.79 & 14.59 & 86.09 & 12.17 \\
\hline 85.57 & 8.72 & 30 & $\begin{array}{c}\text { Textbook-based } \\
\text { (traditional } \\
\text { lecturing type) }\end{array}$ & 72.08 & 17.08 & 80.45 & 13.67 \\
\hline 86.03 & 8.56 & 59 & Total & 72.43 & 15.77 & 83.22 & 12.84 \\
\hline
\end{tabular}

Similar results were obtained in two parallel classes of advertising major.

In the third week after the introduction of the same teaching content and teaching form, two advertising classes were tested for background knowledge. Due to the same teaching content and teaching forms, the difference between the achievements of the two classes is not significant $\quad\left(\mathrm{M}_{27-1}=85.69, \quad \mathrm{SD}_{27-1}=8.79 \quad\right.$ VS. $\mathrm{M}_{27-2}=85.13, \quad \mathrm{SD}_{27-2}=8.67$, Cohen's=0.064,as show in Table5.).

But after the implementation of case teaching method, the analysis of the previous and post-test data showed that case teaching could significantly improve students' academic performance ( Mpretest $=70.96$, SDpretest $=17.23$ VS. Mpost test $=85.77$, SDpost test $=14.25$, Cohen's=0.94, as show in Table5. ).

After the implementation of traditional classroom teaching, the analysis of the pre-test and post-test data revealed that case teaching could improve academic performance moderately (Mpretest $=71.24$, SDpretest $=16.81$ VS. Mpost test $=80.07$, SDpost test $=17.60$, Cohen's $=0.51$,as show in Table5. ) .

In terms of post-measurement data of comparing case teaching and traditional classroom teaching, case teaching could improve academic performance in a moderate way ( Mcase $=85.77$, SDcase $=14.25$ VS. Mlecture $=80.07$, SDlecture $=17.60$, Cohen's $=0.36$, as show in Table5.). 
Table 5. Means and SDs of Background Knowledge, Pretest and Post test Scores in Different of the version of the content in Media management course for Advertising

\begin{tabular}{|c|c|c|c|c|c|c|c|}
\hline \multicolumn{2}{|c|}{$\begin{array}{l}\text { Background } \\
\text { knowledge }\end{array}$} & \multirow[b]{2}{*}{$\mathbf{N}$} & \multirow[b]{2}{*}{ Teaching form } & \multicolumn{2}{|c|}{ pretest } & \multicolumn{2}{|c|}{ Post test } \\
\hline $\bar{M}$ & SD & & & $\mathbf{M}$ & SD & $\mathbf{M}$ & SD \\
\hline 85.69 & 8.79 & $\begin{array}{c}27- \\
\text { class1 }\end{array}$ & Case-based & 70.96 & 17.23 & 85.77 & 14.25 \\
\hline 85.13 & 8.67 & $\begin{array}{c}27- \\
\text { class2 }\end{array}$ & $\begin{array}{l}\text { Textbook-based } \\
\text { (traditional } \\
\text { lecturing type) }\end{array}$ & 71.24 & 16.81 & 80.07 & 17.60 \\
\hline 85.41 & 8.64 & 59 & Total & 71.10 & 16.86 & 82.92 & 15.86 \\
\hline
\end{tabular}

\subsection{The utility of the story to attract students' attention and boost their memory}

Daniel asserted that good teachers shared the following qualities: 1. telling jokes, telling stories, and being gentle; being able to Attract the attention of students so that they are willing to get close to the teacher and into the classroom; 2. Being able to connect key points so that students could comprehend and remember them. He thought that the human brain preferred stories so much that psychologists sometimes thought stories have a "psychological advantage." Therefore, turning a teaching plan into a story is good for students' comprehension and memory[8].

Daniel T. Willingham thinks thought that most stories include four principles, often referred to as the " $4 \mathrm{C}$ principle." Causality indicates that the event occurred with a cause and consequence. Conflict is formed between a target and the forces blocking the target. Teachers can prepare lessons around conflict, construct cases, and rewrite stories. Complications are the branches that will make the story more interesting. Characters are indispensable elements around whom a good story revolves. The key to express personality is action, through which storytellers portray characters.

Based on the 4C principles", the teaching team compiled a story based on the facts documented in a biography[9] about the significance of cash flow to the continued operations of media companies.

The timeline of the story went as follows: the boss went to buy companies, the CFO went to raise money, the banks to make loans and collect debts, the fairy came to the rescue.

Teacher: Do you know Murdock?

Student:Yes, the media magnet in news media ( or confused, no)

Teacher: Good. Thumb up for you! (Praising is important for students) Do you know Wendy Deng? (The boom in social media is proof of the power of exchanging "gossip" [10]. The Teacher introduced gossip in the classroom to help attract students' attention)

Student: Yes( it turned out more students knew Wendy than Murdock ).

Teacher: You're going to pay attention to the high profiles in the media industry as you're focusing on gossip. Murdock is a big shot in the media (Repeating students' answer is also a reward for students ). But he relied on Ann Ryan, a 34-year old vice president of Citibank to overcome the financial crisis of his company. Do you believe that?

Student: It must be so since you ask in such a way.

teacher: : Smart! Call for you (Call is one of the "Top 10 Network Terms of 2017" to mean support. Using network language draws students closer to the teacher) ! News Corp. has been purchasing all along the way and merged and acquired many companies to become bigger and stronger and international. But where did the money come from? 
Student:To loan from the bank.

teacher: Yes, from the bank! (to have eye contact with the student to acknowledge his answer). News Corp. has an incredible CFO - Richard Salazen who joined News Corp. USA as Chief Financial Officer in1974, He collected verbal commitments of \$2 billion and \$1 billion from Europe and the United States in just one day in 1998, and signed a written agreement within the same week. But borrowed money has to be returned with interest. News Corp used short-term loans to save interest expenses in the hope of converting short-term loans into long-term debts when long-term lending rates would be lowered. But it turned out that market interest rates did not fall but rise which brought about Murdoch's News Corp.'s huge financial crisis in 1990. Without cash to pay off its forthcoming debts, News Corp survived the storm with the Dolphin Rescue Plan of Citibank, News Corp.'s largest service bank and largest creditor. For 10 years up to 1990, Murdoch was committed to mergers and acquisitions, leaving debt management to Richard Salazen, who had been News Corp's treasurer for more than a decade, and then Dave Devo, who replaced Richard Salazen during News Corp.'s financial crisis for his lack of financial warning.

The key to telling a story in conjunction with the course knowledge point is to adjust, and in the process of adjustment, you need to find that one part of the story works, some parts need to be polished, some parts need to be discarded, which will make the story more popular, more interesting, and the key is to associate with the knowledge point. Stories are masters of attracting attention.

Stories not only attract students' attention, but also create long-term memories. "I remember the importance of cash flow because my teacher told me the story about Rupert Murdoch turning to the vice president of Citibank for help in 1990 when he was in financial crisis. I also shared the story to friends who were running short of cash because they were investing in houses and shops" the 2010 graduate, who was a junior at that time, said in a remote interview. Similarly, the remaining four graduates also mentioned stories and related knowledge points that they remembered in class that year. It is worth the hard work of finding the story and adapting the story to the teaching content.

\subsection{Attracting attention and improving heads-up rate in the classroom}

Classroom head-up rate refers to the ratio between the number of students who listen carefully to the total number of students during class. Many colleges and universities use it as an important measure of classroom quality in China.

As teachers, you know that changes or shifts in the classroom can keep students active and re-focus their attention. If the teacher has been speaking, then a little visual stimulation (such as a video or a picture) can make a good difference - the students look up.

From the lectern, the teacher can get a rough estimate of the head-up rate at a glance. A more nuanced way to count heads-up rate of the classroom: classroom video, after-class viewing.

It is difficult for teachers to fully observe the response of the class when they are teaching, and there is also the question of cost involved in having a class observer. The cheapest and most convenient way is to make a video of the class and view it yourself after class. In order to avoid the unnatural of teachers and students in front of the VCR, from the beginning of the course in the classroom can be filmed to the vast majority of the space in the classroom to set up shooting students' seats, students are required to sit within the scope of the camera, and inform students that the video is for teaching research to improve teaching, will not be used for any other commercial purposes, the video will be deleted within 2 months after the end of the course. At first, teachers and students weren't used to having classroom space for cameras, but after a few weeks, everyone got used to it and 
almost ignored the camera. Usually after three weeks, teachers and students have no feelings about the presence of the camera. So the fourth week is the best time to start by video to see the student's class heads-up rate. A 40-minute lesson that looks at the student's head rate in the first minute, 6th minute, 11th minute, 16th minute, 21 st minute, 26th minute, 31 st minute, 36th minute, 40th minute. So there are aggregate 9 fixed time nodes to observe the student's heads-up rate, while setting some motorized point-in-time to observe. Generally choose the time point of general head-up, the time point of general head-down, analysis of the content and form taught by teachers before this point in time, in order to make reinforcement or improvement. In fact, any teacher should design and implement instruction based on the assumption that what students really want to do is play with their phones, read novels, or skip class.

Teachers also need to put themselves in students' shoes, teachers spoke in a dry and uninteresting way, no fun, why should students listen? Imagine the ideal classroom: so interesting teachers and students, in such an interesting classroom, teachers and students do interesting things together, how can the classroom be boring!

\subsection{Praise students skillfully to inspire students' enthusiasm for learning}

The teacher checked the student's work log and praised students' efforts not abilities on a process-based basis because of differences in abilities between individuals. praise students' attitudes to being responsible for their assignments, praise the details of students' assignments (PPT templates are good, background music is good, color schemes are good, pictures are used properly, and video clips are superb).

\subsection{Research reports and course presentations by media companies conducted by student groups are a reflection of expertise and comprehensive ability}

Research reports that go through at least 8 weeks of preparation time are produced by team members during the last 6 weeks of course, as the research reports are framed (Table6. ) Each framework corresponds to the point of expertise in the media management course, and the matching of information within each framework in their research reports reflects whether the student's understanding of the course's expertise is correct or not.

In the group presentation, can distinguish the group member's information collection ability, data analysis ability, the appropriate meaning interpretation ability, team work ability, the ability to manufacture PPT, the ability to edit visual audio footage, etc.

Table 6.Research report Framework of media company' management.

\begin{tabular}{|c|c|}
\hline NO. & Research report framework \\
\hline 1 & History of Media companies including their history of mergers and acquisitions \\
\hline 2 & $\begin{array}{c}\text { Structure of media company's organization( business, brands ,horizontal and vertical } \\
\text { industry chains) }\end{array}$ \\
\hline 3 & $\begin{array}{c}\text { Businesses of media companies, revenues, and its distribution, business changes within5 to } \\
\text { ten years; asset value changes, market value changes; development in China and overseas }\end{array}$ \\
\hline 4 & $\begin{array}{c}\text { Management of media companies:including but not limited to media product operation, } \\
\text { advertising operation, cross-media operation, capital operation and so on }\end{array}$ \\
\hline 5 & Human resource management of media organizations \\
\hline 6 & Technical management of media companies \\
\hline 7 & Financial and property management of media companies \\
\hline 8 & Management, support and restrictions on the country in which the media company operates \\
\hline
\end{tabular}




\section{Conclusion}

The results show that case teaching can significantly improve a student's academic performance (Cohen's=0.99 for journalism, Cohen's=0.94 for advertising), whilethe traditional teaching format embedded in the question-and-answer approach can moderately improve a student's academic performance (Cohen's $=0.54$ for journalism, Cohen's $=0.51$ for advertising). This is also in line with the teaching evaluation from students. The two levels of teaching supervisors from schools and colleges have given full affirmation to the case teaching method and question-and-answer teaching method.

Although case teaching can improve students' academic performance to a greater extent than traditional teaching, traditional teaching also has a significant positive impact on improving students' academic performance. Because the traditional teaching used in this study for testing is embedded in the question-and-answer teaching method, through the form of question-and-answer can still attract the attention of students, starting with attention, affecting students' understanding of knowledge, and then produce memories. Through question-and-answer teaching, stimulate classroom interactive teaching, training students to talk and express. In P. Freire's book The Education of the Oppressed, Freire puts forward the famous concept of "dialogue education". According to Freire, education is not about who educates who, nor about educating oneself, but about learning from each other through the world. Education is equal and interactive. Dialogue is a kind of liberation, not dialogue is an oppression. "[11]

Through dialogue,words such as "students-of-the-teacher"and"teacher-of-the-students" no longer exist, and new terms emerge:teacher-student sand students-teachers. Teachers are no longer just teachers, in the dialogue with students, teachers themselves are also taught, students are being taught at the same time, in turn, are also teaching teachers, they work together to grow together. [12] When our teaching is based on dialogue and respect, students are more willing to be educated, learn faster, learn better, and achieve pleasant teaching.

It is beneficial to assign students moderately difficult homework, and solving problems that are too simple or too difficult can make people unhappy. Solving problems with moderate difficulty can bring pleasure. Pleasure comes from the process of solving a problem. Assigning students to study the operation and management of media companies in groups needs to find a lot of data. Relevant books, newspapers and periodicals, and relevant websites (including the official websites of media companies and industry websites) are well-deserved gold mines in the course learning process, especially when it comes to news. GayeTuchman believed news agency from the distribution of people want to know, need to know and should know the information, not only spread knowledge, and the normative knowledge.[13] Cui Di argued News is a kind of shared knowledge about human survival community or some kind of public life and news is a kind of knowledge that motivates people to share.[14] Students are also guided to pay attention to some WeChat public accounts, Weibo, official websites of media enterprises, interview programs, etc., so as to obtain information from them, so that they can learn factual knowledge anytime and anywhere, and learn to explain the core concepts of the curriculum with associated facts.

Because teachers in the early and middle of the teaching process have introduced many related cases, stories to interpret the core concepts of the curriculum. It's easy to follow suit, and in the course of their homework, they've trained teamwork, information search, data analysis, language expression,PPT production, audio and video editing, and so on.

Course teaching is a journey to seek knowledge, teachers and students accompanied by peers, teachers are the guide of knowledge tour, students can also have a surprising discovery from time to time, when students face difficulties and cringe, the teacher should encourage students to move forward, tell students to climb the mountain after the unique scenery! 
To sum up, teachers with empathy to carry out teaching can effectively improve teaching. Empathy translates as"feeling the feelings of others". [15]Teachers pay attention to the feelings of students, feel the feelings of students, take appropriate action against the feelings of students, the action taken in this study is to implement case teaching, story teaching, question and answer teaching, Integrating story-based teaching and question-andanswer teaching into case-based teaching, to attract students' high concentration of attention, stimulate students' strong interest and cultivate students' positive emotions, as far as possible to ensure moderately difficult and pleasant learning process.

\section{Acknowledgments (optional)}

Thanks to Erasmus + Russian and Chinese Higher Education Teaching Practice Capacity Building Project

Thanks to Harvard Business Publishing Education for giving me a free faculty account to share their case studies.

\section{References}

1. P. Freire, Teachers as Cultural Workers: Letters to Those Dare to Teach, Boulder: Westview Press. 116 (2005)

2. Danie Schugurensky, Qiuxia Zhou, Paulo Freire, Heilongjiang Education Press, Harbin, China. 99 (2016)

3. Editorial team of the Harvard Business School Case Book of Management and MBA, Harvard Business School Management and MBA Case Book (set of 10 volumes), Central Compilation Press, Beijing, China. 35 (2018)

4. W. Lorin Anderson, Xiaoping Jiang, A Taxonomy for Learning, Teaching, and Assessing-A Revision of Bloom's Taxonomy of Educational Objectives (Complete Edition,Chinese version) Foreign Language Teaching and Research Press. 22 (2009).

5. P. Alexander, J. Kulikowich, S. Schulze How subject-matter knowledge affects recall and interest. American Educational Research Journal. 31 (2). 313 ( 1994 )

6. A. Shapiro How including prior knowledge as a subject variable may change outcomes of learning research . American Educational Research Journal , 41 (1). 159 ( 2004 )

7. Neuman, S. B., Kaefer, T. and Pinkham, A.Building Background Knowledge, Reading Teacher, 68(2). 145 2014) doi: 10.1002/trtr.1314

8. Daniel T. Willingham, Meng Zhao Why don't students like school? Jiangsu Education Press, Nanjing,China, 50 (2010)

9. William Shawcross, Xinzhi Fan Rupert Murdoch: The birth of a media empire. World knowledge press. Beijing, China, 240. 261 (2001)

10. Anthony Tasgal, Chaoying Yang, The storytelling book. China Friendship Publishing Company, Beijing, China. 76 (2019)

11. Zhicheng Huang, Pedagogy of the oppressed - Freire's theory and practice of emancipation education, People's Education Press, Beijing, China. 8 (2003)

12. P. Freire, Pedagogy of the Oppressed (30th Anniversary Edition) Jianxin Gu ( translate ), East China Normal University Press,Shanghai,China. 44(2014)

13. GayeTuchman, making news, Huaxia press. 30 (2008)

14. Cui Di. Media Knowledge: Knowledge Research from the Perspective of Communication . Shanghai: Fudan University Press. 32 (2019) 
15. Daniel Goffman, Ping Wei Social Intelligence : The New science of Human Relationships, CITIC Publishing House,Beijing, China. 60 (2018) 